\title{
The Structure and Content of Namban Trade
}

The purpose of this chapter is to understand the structure of Namban trade through the analysis of Spanish records that inform us about import and export goods, places of production, trade prices, and the selling prices of the official trade that was undertaken by the ships of the Capitão-mór, assigned by the king. Numerical data about trade has not been well provided, with the exception of research by Takase Kōichirō (高瀬弘一郎), ${ }^{1}$ who extracted information about the import volume of raw silk from documents relating to the Jesuits and other organizations. ${ }^{2}$

Thanks to Takase's research, Jesuit missionary reports have been shown to provide excellent and reliable historical information about Portuguese trade in East Asia. For example, in 1559 the Jesuits of Japan concluded a contract to load fifty picos of raw silk into the ships of the Capitão-mór every year, such that Namban trade would give them a financial basis for their missionary work. Other materials, such as gold, were also sent from Macao, accruing good profits, all of which were used as the operating foundation of their missionary activities. Furthermore, we can assume that the Namban trade and the Jesuits were closely linked based on the fact that the Jesuits rendered a fund consignment service from a local lord in western Japan (saigoku daimyō 西国大名) and intervened in raw silk package deals. Their missionary report gives us some details of the trade. Missionaries were sensitive to information about merchant ships on which their livelihood depended, but they did not keep many records of the contents and volumes of loaded goods. Therefore it is difficult to reconstruct a complete picture of the Namban trade from this information.

Iwao Seiichi (岩生成一), who systematically studied red-seal ship trades, comments about the detailed records of imported and exported goods: "there

1 Kōichirō Takase, "Macao Nagasaki Kan Bōeki no Sō Torihiki-daka, Kiito Torihiki-ryō, Kiito Kakaku" [Total Turnover, the Raw Silk Trade Volume and Prices of the Trade between Macao and Nagasaki], in Kirishitan Jidai no Bōeki to Gaikō [Trade and Diplomacy in the Kirishitan Period] (Tokyo: Yagi Shoten, 2002), 3-5o.

2 A concrete example of the trade in Macao is given by a Florentine merchant, Francesco Carletti, Ragionamenti di Francesco Carletti sopra le cose da lui vedute ne' suoi viaggi si dell' Indie Occidentali, e Orientali come d'altri Paesi. English translation; Francesco Carletti, My Voyage around the World, trans. Herbert Weinstock (London: Methuen, 1965).

(C) MIHOKO OKA, 2021 | DOI: 10.1163/9789004463875_005

This is an open access chapter distributed under the terms of the CC BY 4.0 license. 
are quite few materials both in Japan and other countries and even if we have them, they are in fragments." He mainly used Dutch sources for his study. ${ }^{3}$ The most fruitful source material concerning external trade in the early modern period is from the Voc, which handled organized trade activities and kept detailed correspondence between individuals and local factories. Nagazumi Yoko (永積洋子), ${ }^{4}$ Kato Eiichi (加藤榮一), ${ }^{5}$ and Ishida Chihiro (石田千尋) ${ }^{6}$ all introduced detailed evidence about the goods that were traded in their research. They also investigated the diplomatic policy of the Tokugawa Shogunate in the first half of the 17th century and, importantly for this chapter, imported and exported goods. ${ }^{7}$

Although the documents analyzed in this chapter were reprinted in Spanish, ${ }^{8}$ and translated into English some years ago (Blair \& Robertson: The Philippine

3 Seiichi Iwao, Shuin-sen Bōeki-shi no Kenkyū [Study of the History of the Red-seal Ship Trade] (Tokyo: Kōbundō, 1958), 292-306.

4 Yōko Nagazumi (ed.), Hirado Oranda Shōkan no Nikki [Diaries Kept by the Dutch Factory at Hirado], 4 vols (Tokyo: Iwanami Shoten, 1969-1970).

5 Eiichi Katō, "'Hirado'Jidai Zenhan-ki no Oranda-sen: Nihon Bōeki no Jittai" [Dutch Ships in the First Half of the "Hirado" Era: The Actual Situation of the Japanese Trade], Tabako to Shio no Hakubutsukan Kenkyū Kiyō [Bulletin of the Tobacco \& Salt Museum] 2 (1987); Katō, "Rengō Oranda Higashi Indo Gaisha no Senryaku Kyoten toshite no Hirado Shōkan" [The Dutch Factory at Hirado as a Strategic Base for the East India Company of the United Kingdom of the Netherlands], in Takeo Tanaka (ed.) Nihon Zen-Kindai no Kokka to Taigai Kankei [The State and the External Relations of Japan in the Pre-Modern Period] (Tokyo: Yoshikawa Kōbunkan, 1987).

6 Chihiro Ishida, Nichi-Ran Bōeki no Shiteki Kenkyū [Historical Study of the Trade between Japan and the Netherlands] (Tokyo: Yoshikawa Kōbunkan, 2004); Ishida, Nichi-Ran Bōeki no Kōzo to Tenkai [Structure and the Development of the Trade between Japan and the Netherlands] (Tokyo: Yoshikawa Kōbunkan, 2009).

7 For recent studies on the first half of the 17 th century, see Yasuko Suzuki, Kinsei Nichi-Ran Böeki-shi no Kenkyū [Study of the History of the Trade between Japan and the Netherlands in the Early Modern Period] (Kyoto: Shibunkaku Shuppan, 2004); Keisuke Yao, Kinsei Oranda Bōeki to Sakoku [The Dutch Trade and National Seclusion in Early Modern Japan] (Tokyo: Yoshikawa Kōbunkan, 1998); etc.

8 Francisco Colin, Labor Evangélica: Ministerios apostolicos de los obreros de la Compañia de Iesus, fundación, y progressos de su provincia en las islas Filipinas, tomo III, ed. Pablo Pastells (Barcelona: Imprenta y Litografía de Henrich y Compañía, 19oo-19o2; first published Madrid, 1663), 219-221. 
Islands; Boxer: The Great Ship from Amacon), ${ }^{9}$ a full analysis of the information they contain remained to be done. ${ }^{10}$

Since this information enables us to create a detailed picture of Namban trade I have revisited these sources in order to highlight and describe the trade's dynamics. The original text is housed in the General Archive of the Indies, Seville, Spain. ${ }^{11}$ As already mentioned, the available reprints contain glaring mistakes and lack explanatory notes. These problems have led to erroneous conclusions and an incorrect impression of the information the sources hold.

The date of the original writing is not known, but it is often assumed to be around 16oo. The document might be based on an old catalog of the General Archive of the Indies, in which this date is given. ${ }^{12}$ The author may have been Spanish: he indicated that Spain was his home country and wrote about

Emma Helen Blair \& James Alexander Robertson, The Philippine Islands 1493-1898, vol. 19 (Manila, 1973; second edition), 303-319; Charles Ralph Boxer, The Great Ship from Amacon: Annals of Macao and the Old Japan Trade 1555-1640 (Lisbon: Centro de Estudos Históricos Ultramarinos, 1959), 179-184.

10 The research paper by Kobata Atsushi (小葉田淳) regarding the relative values of gold and silver was the first in Japanese to cite a part of the English translation. In addition, Okamoto Yoshitomo (岡本良知) translated and introduced elements of the trade with Japan in his Memorandum of Trading Goods with Japan in Macau by Obscure Spanish. However, Okamoto uses Spanish reprints and English translations as his original sources, and they contain glaring mistakes (Kobata points to the fact that precise translations had not been established) and almost no comments or explanatory notes about special terms. Kōichirō Takase also cites parts of the Spanish reprint and English translation according to Okamoto's translation that referred to them. Okada Akio (岡田章雄) cites the English translation in his research paper about trade in the early modern period.

The manuscript used for existing reprints and translations is Document 31 in Box 46 of Patronato (hereinafter Document A) in the General Archive of the Indies. Apart from this document, there exists a manuscript beginning in the middle of the document; this is Document 3 in Box $263^{-2}$ of Patronato (hereinafter Document B). The remaining part of Document $\mathrm{B}$ begins in the middle of a list of goods brought from China to Goa and continues to the end of the document. While Document A must also be a manuscript, considering points such as smooth writing and no date or signature, Document B seems to have been created not from the same original text as Document A, but from Document A itself, considering the mistakes included in it. The beginning of Document $\mathrm{B}$ does not make sense; it seems it was once a complete version, whose first half has been lost for some unknown reason. Given the mistranscriptions, the writer of Document B was obviously not familiar with the place names and products of Asia.

Yet the reason for this date lies in the thirty-one documents that are included in Box 46 of Patronato, most of which were written in the later part of the 16th century. The content of this box is ordered chronologically and documents with unknown date are bundled at the end. Box 46 is one of sixteen boxes containing documents from 1518 to 1619 named "Patronato S2/SS12 discovery. The Maluku Islands and spices." Box 45, previously Box 46, contains documents dating from 1525 to 1537 and Box 47 from 1605 to 1619 follows. Document 
the Portuguese from a third-person perspective. The Captaincy General of the Philippines seemed to stand in the background of the document. Assuming it was a report on trade conducted by the Portuguese between Japan and Macao, we can try to identify an approximate date for it. The Captaincy General of the Philippines in Manila was established in 1571, when Spain undertook to govern the Philippine islands and to trade in the East China Sea. ${ }^{13}$

\subsection{Spanish Interest in the Japan Trade}

Some Spanish individuals, including Augustinians and Franciscans, were on board Vicente Landeiro's ship that sailed from Macao to Hirado in 1584. Matsura Shigenobu (松浦鎮信), the territorial lord of Hirado, entrusted them with a letter asking the Spanish government in the Philippines for commercial transactions and amity. A galleon ship from Macao to New Spain (Mexico) drifted down to Amakusa (天草) in 1587, and a Fragata ship arrived in Satsuma in a similar way. ${ }^{14}$ Toyotomi Hideyoshi (豊臣秀吉) sent letters to the Spanish government in the Philippines, demanding they submit to him, in 1591 and 1593; but official relations were not established owing to the unstable situation in Japan. For example, Dasmariñas was killed in a riot by Chinese sailors during his expedition to Ternate Island. Hideyoshi confiscated loaded goods from the San Felipe, a galleon drifting down to the Urado (浦戸) Port, Tosa (土 佐), from Manila to Mexico in 1596. During this period mendicant orders came to Japan from Manila and started missionary work. ${ }^{15}$ In addition, a Japanese merchant ship traded in Manila. ${ }^{16}$

A in Box 46 is therefore from the latter part of the 16 th century, but this fact is not enough to conclude it was written in 1600 .

Regarding the Spanish government and multi-ethnic society of the Philippines, see Tremml-Werner's recent work. Birgit Tremml-Werner, Spain, China, and Japan in Manila, 1571-1644: Local Comparisons and Global Connections (Amsterdam: Amsterdam University Press, 2015).

Yoshitomo Okamoto, 16 Seiki Nichi-Ō Kōtsū-shi no Kenkyū [Study of the History of Interaction between Japan and Europe in the Sixteenth Century] (Tokyo: Hara Shobō, 1974; first published Tokyo: Rokkō Shobō, 1942), 48o-481, 494.

15 The Franciscans started their mission in Japan in 1593, then the friars of Dominicans and Augustinians in 1602 .

16 Antonio de Morga, Philippine Shotō-shi [Sucesos de las Islas Filipinas], trans. Yanai Kenji \& Kanki Keizō, Dai-Kōkai Jidai Sōsho [Series of the Age of the Discovery], series I, vol. 7 (Tokyo: Iwanami Shoten, 1966), 392; Morga, History of Philippine Islands (Scotts Valley, CA: Createspace Independent Publishing Platform, 2015); Juan Gil Fernandez, Hidalgo to Samurai:Jüroku-Jünana Seiki no Hispania to Nippon [Hidalgos y samurais: España y Japón en los siglos XVI y XVII], trans. Hirayama Atsuko (Tokyo: Hosei University Press, 20oo); Juan Gil Fernandez, Hidalgos y samurais: España y Japón en los siglos XVI y XVII (Madrid: Alianza Editorial, 2007). 
I also focus on a historical source (Salazar's note) held in the National Historical Archive of Spain (Archivo Histórico Nacional). ${ }^{17}$ The information provided in this source prompted Spain to take an interest in Japan in the late 1580s. Japanese historians have long known about this source, but it has not been analyzed in sufficient depth. ${ }^{18}$ The source contains information that a Japanese visitor to Manila was communicating with the Spanish governor-general of the Philippines. ${ }^{19}$

This communication occurred in 1587 , a time when Luzon and other islands of the Philippines were under the occupation of the Spaniards. In that year, a group of Japanese merchants arrived in Luzon. The merchants met Domingo de Salazar, who, as Bishop of Manila, was the leading Catholic prelate of the area. The source is a compilation of information on Japan that the bishop gleaned from the merchants. Enclosed in the source is a document from the merchants themselves. The document describes the various regions in Japan, featuring a particularly detailed account of Iwami (石見), the location of a silver mine. This account includes the following statement: "Here lies plenty of silver. The Portuguese visit here" (Ay mucha plata. Aqui van los portugueses). Iwami boasted many valuable natural harbors, including Okidomari (沖泊) in Yunotsu(温泉津). Outside Yunotsu it had Hamada, one of Japan's foremost commercial ports.

The source also includes a list of sixty-seven Japanese domains in exquisite handwriting by a Japanese person. Besides the Iwami domain, the list includes a detailed account of the Aki domain and of the Mori family, who ruled the domain. The pages containing this geographic information were bundled together with a map of Japan drawn on a single sheet. The map was drawn according to a cartographic style that historians call the Gyoki-zu ( 行基図) style (it is known among historians of cartography that a Buddhist

17 AHN, Coleccion Diversos 26, no. 9, Documentos de Indias, 267bis, Informacion original recibida por Fr. Domingo Salazar, Obispo de Filipinas acerca del Japon (1587), fecha 1587, julio, 4. Incluido la mapa de Japón.

Hiroshi Nakamura, a Japanese historian of cartography, introduced the source to the community in 1939 in the French language. At the time, Nakamura was unable to accurately decipher the Spanish-language account of Iwami. Hiroshi Nakamura, "Les Cartes du Japon qui servaient de modèle aux cartographies européeans au debut des relations de l'Occident avec le Japan,"Monumenta Nipponica 2, no. 2 (1939).

19 A manuscript copy of the same document that does not contain the maps and local descriptions in Toyo Bunko in Tokyo. MS-14 Japon-Filipinas. Copia de la peticion de los Japoneses- ... a D. fray Domingo de Salazar...This copy is transcribed and analyzed as below. S.J. Johannes Laures, "Nihon to Philippine Shotō tono Shoki no Kōtsū ni kansuru Ichi-komonjo" [A Document Relates the First Contact between Japan and Philippines], in Kirishitan Kenkū, no. 5 (Tokyo: Yoshikawa Kōbunkan, 1959). 
THE STRUCTURE AND CONTENT OF NAMBAN TRADE

55
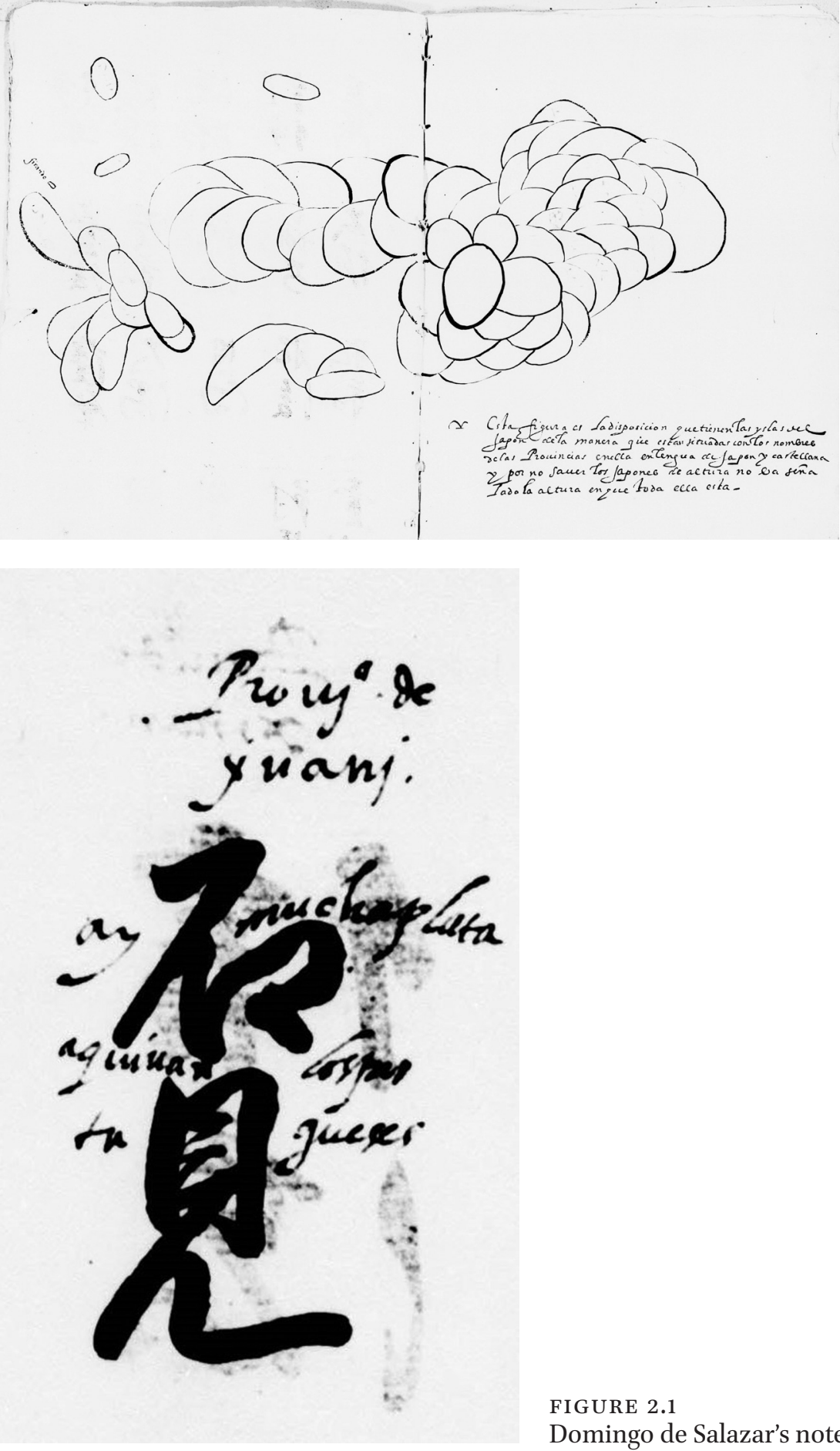

FIGURE 2.1

Domingo de Salazar's note

Mihoko Oka - 9789004463875

Downloaded from Brill.com®4/26/2023 11:52:25 AM

via free access 
priest named Gyoki provided the first template for this style). The map was most likely drawn by a Japanese person. By collating the map with the list of sixty-seven domains, one can get a rough idea of the layout of the independent jurisdictions (known as bunkoku). Notably, however, the map omits Japan's northernmost island Hokkaido, which was then known as Ezochi. Among the Portuguese maps of the time, which represented the cutting edge of European cartography, there is a map produced in 1561 featuring a landmass that bears a striking resemblance to Hokkaido/Ezochi. Although Japanese cartographers of the late 16th century may have been aware of Hokkaido/Ezochi's existence, they omitted it from their maps of Japan. The source provides evidence that Spaniards in Manila had accessed accurate information about Japan's geography and Jesuit activity in Japan as early as 1587 .

Thus the Spanish in Manila seemed to be fully aware of the existence of Japan by the end of the 16 th century. ${ }^{20}$ Tokugawa Ieyasu (徳川家康) seized power after the death of Hideyoshi after the Battle of Sekigahara (16oo). He strove for internal unification and attempted to bring calm to the country's foreign affairs. He also focused his attention on trade with New Spain (Mexico), and in 1598 he asked Jerónimo de Jesús, a Franciscan, to encourage Spanish ships to sail from Manila to Uraga (浦賀), a port in his territory. In 16o1 he sent a letter to the Governor-General of Manila to ask for amity and commerce. A ship from Manila bound for Edo region in 1602 entered port at Bungo (豊後 Oita) owing to bad weather conditions, and in 1608 trading ships came to the Uraga port. ${ }^{21} \mathrm{~A}$ large volume of raw silk was brought from Manila to Nagasaki (長崎) in 1605, greatly affecting the Macao merchants' raw silk trade. ${ }^{22}$

Based on these considerations, we can assume the document was written after 1584 when Matsura asked about trading and before 1602 when the official trade started. In other words, it was during a period when the Captaincy General of the Philippines was seriously investigating trading possibilities with Japan and the Spanish in Manila, having already resolved the situation regarding Portuguese trade in around 1602 .

Boxer reasons that the author of this document may have been Pedro de Baeza, a Spaniard who stayed in Macao for six years. ${ }^{23}$ As the document says

20 According to Gil Fernandez, Hidalgo to Samurai, 24-26, the people of Manila feared Hideyoshi's plan to invade Manila as a real threat.

21 Kōichirō Takase, "17 Seiki Shotō ni okeru Waga-Kuni no Spain Bōeki" [Trade between Japan and Spain in the Early Seventeenth Century], in Kirishitan Jidai no Bōeki to Gaikō [Trade and Diplomacy in the Kirishitan Period] (Tokyo: Yagi Shoten, 2002), 88-122.

22 Ibid., 100-101.

23 Boxer, The Great Ship from Amacon, 179; Boxer, Christian Century in Japan 1549-1650 (Berkeley \& Los Angeles: University of California Press, 1951), 425-427. 
"I didn't remember the net price nor selling price" concerning the cargo of tin, and "I loaded on the ship from China to Japan," it is certain the author actually joined traders with Japan on a Macao trading ship. With regard to the whole description, it is also certain the author stayed in Macao and saw the mutual trade in Guangzhou (広州) with his own eyes. Boxer does not give any other grounds for these conclusions, except to point to the possibility that Pedro de Baeza had the necessary experience to be in this position. Another memorandum written by Baeza (1609) to which Boxer refers states that the "Philippines don't produce gold." ${ }^{24}$ But this contradicts the detailed reference to gold production in the Philippines at the end of the same document. According to Boyajian, Baeza was from a converted Jewish family that formed a network on the route from the new continent to Manila. ${ }^{25}$ As the author's name is not on the document, we can only make suppositions. It is certain, however, that the author was Spanish, familiar with Portuguese trade in Asia, and that he had experience of sailing to Japan.

As mentioned earlier, the first reprint of this document was contained in Labor Evangelica (1663). The mistakes included in that edition prove that the later English translation used this reprint as an original text, and that it was neither a new translation nor a reprint from the original book. ${ }^{26}$ Therefore, I have decided to analyze the content in light of the correct translation as opposed to the transliteration of the original book.

The contents of the "Memorandum of Trading Goods of Portuguese Ships" (hereinafter Memorandum) can be categorized into five broad types: "Loaded goods in ships from China to Japan," "Loaded goods in ships from China back to India," "Loaded goods in ships from Goa to China," "Detailed memo of goods in Guangzhou," and "Trading goods of Portuguese and their production area." The first three categories contain mainly goods that were transported on the main sailing routes, such as China to Japan, China to India, and Goa (India) to China. They mostly do not include goods bought and sold in port markets in Southeast Asia. We can suppose therefore that the records regarding port markets in

\footnotetext{
24 Boxer, Christian Century in Japan 1549-1650, 425-427.

25 James Boyajian, Portuguese Trade in Asia under the Habsburg 1580-1640 (Baltimore: The Johns Hopkins University Press, 1993).

26 To give an example, there are common errors as çangalas (canga in the original), De Far (Defar in the original, corruption of the name of the city Dofar), Sumatra (Somaria in the original).
} 
Southeast Asia and their production were inserted as part of the fifth category, "Trading goods of Portuguese and their production area." Existing research about Namban trade has covered trade between Japan and Macao and has not focused on markets in Guangzhou and the hinterland. These descriptions prove that Macao was a main distribution point. Chinese products brought to Japan were mainly traded in markets in Guangzhou. Products destined for Japan were traded in Guangzhou in April and May and those for Goa in September and October. ${ }^{27}$

\subsection{Chinese Commodities for the Japanese Market}

Chinese products destined for Japan make up the largest and most detailed category of goods, with raw silk and silk textiles being the lead products. Historians have not yet focused on twisted yarn in raw silk, but according to the imported volumes there was not a big difference between 500-600 picos of white yarn and 400-500 picos of twisted yarn. One pico is equivalent to approximately $6 \mathrm{o} \mathrm{kg}$. However, the profit ranged from 70 percent to 185 percent according to quality. The Memorandum of the Procurador in Japan (see Chapter 6), possibly written by Tçuzu Rodrigues S.J., states that "It is not bad to trade 5 to 6 or 10 boxes of rolls of cloth and twisted yarn. They must be thick, high quality, and crimson. That is because they absorb [exchange] silver well and are sold well to raise stable profits." Twisted yarn was, as we can see, the best-selling good. The total volume of imported white yarn and twisted yarn was about 1,00o picos. This record refers to the trade at the end of the 16th century, indicating there was a big difference from the more than 2,500 picos of imported raw silk taken to Japan by Portuguese ships in $1600 .{ }^{28}$

As the total volume of imported raw silk, white yarn, and twisted yarn taken to Japan by Dutch ships from the factory in Patani was 6,205 catty (equivalent to 62 picos), ${ }^{29}$ Portuguese ships clearly had a monopoly in the Chinese raw silk market at the time. Though the voc started to trade with Japan in 16o9, the volume of imported goods was quite small in the beginning compared with the amount that Portuguese ships imported.

27 Kazuo Enoki, Min-matsu no Macao [Macao in the Late Ming Era], vol. 5 of Enoki Kazuo Chosaku-shū [Works of Enoki Kazuo] (Tokyo: Kyūko Shoin, 1993), 186.

28 Takase, "Macao Nagasaki Kan Bōeki no Sō Torihiki-daka," 23.

29 Kazuhiro Yukutake, "Ieyasu Seiken no Taigai Seisaku to Oranda-sen Bōeki: 'Hirado Shōkan Shoki' no Nichi-Ran Bōeki Jittai” [Foreign Policy of Ieyasu and the Dutch Ship Trade: The Actual Situation of the Trade between Japan and the Netherlands in the Early Phase of the "Period of the Dutch Factory at Hirado"], Tōkyō Daigaku Shiryō Hensan-jo Kenkyū Kiyō [Research Annual of the Historiographical Institute, University of Tokyo] 17 (2007): 94. 
Apparently because the trading volume of Portuguese ships was so large, Dutch imports were excepted from the pancada (wholesale price). There was no need to control the prices.

According to the records, Portuguese ships imported 1,700-2,10o rolls of silk textiles. Only 558 rolls of silk textiles were imported by Dutch ships in 1615 , so the difference in volume is obvious. ${ }^{30}$ Three thousand rolls of cotton textiles were imported, a significantly larger volume than silk. This shows that not only luxury goods but also many everyday goods were part of the Namban trade. The same situation pertained with ceramics, which will be analyzed later. However, compared with cotton, silk brought a greater level of profit, with a selling price per roll that was five times higher.

Together with raw silk from China, gold ingots (insukin 印子金) were a leading product. At the beginning of the "Detailed memo of goods in Guangzhou," gold is mentioned in the following way: "One tael of high quality gold is equivalent to seven taels of silver" (see Table 2.1). According to the study by Kobata Atsushi (小葉田淳), the exchange rate between gold and silver in China from 1573 to 1620 had been considered as "one gold is equivalent to seven or eight silver." ${ }^{31}$ Kobata argues against this rate, quoting an English translation of this Memorandum. He notes that the exchange rate between gold and silver in Japan in the early 17th century could not be proved to be one to eight. The Memorandum therefore was either mistranslated or was referring to a rate in another time period. According to Kobata's research, the exchange rate between gold and silver in Japan in the early 17 th century was one to twelve or thirteen. But this has to remain as speculation. As mentioned earlier, there is no evidence to identify the year of the Memorandum. Editors of English translations sometimes state that Volume 19 contains material dating from 1620 to 1621 together with account documents from the early 17 th century and material that cannot be dated.

Judging from records concerning the market price in Guangzhou of gold (superior), it becomes clear that Kobata did not mistranslate the Memorandum. The rate was 6.6 taels to 8.3 taels for selling in Japan and that of gold (standard) was 5.4 taels to 7.8 taels. Profits from the exchange of standard quality gold were in the region of 44 percent and therefore more than that for superior quality gold. It may be noted that 3,000-4,000 taels are equivalent to $112.5^{-130} \mathrm{~kg}$ in weight. Obata states in his paper that the exchange rate

30 Ibid.

31 Atsushi Kobata, "Nihon no Kin-gin Gaikoku Bōeki ni kansuru Kenkyū" [A Study on the Foreign Trade of Gold and Silver of Japan], Shigaku Zasshi [Journal of the Historical Society] 44-10 (1933): 1402. 
between gold and silver in 1585 was one to 8.32 , which was quite similar to the selling price mentioned in this Memorandum. Based on this information it is possible to suppose that the author of this document wrote his record based on his trade experience in Japan and Macao around 1585, according to the later order of the Captaincy General of the Philippines.

As I will argue in Chapter 6, it is generally known that the Jesuits in Japan consigned raw silk to Macao merchant ships destined for Japan in order to gain profits for their missionary work. The procurador of Macao, that is, the person in charge of the economic matters of the Jesuits also in Japan, fixed the rule that "all other than goods (except necessary cotton) must be invested into gold. [...] we have to make our best effort to invest into gold with 4,000 taels at a minimum every year."32 A Jesuit Father Visitador for the East Indies, Alessandro Valignano, established this rule when he visited China and Japan in the 158 os. The rule was further revised in 1611-12 by Pasio, and again in 1618 by Vieira. ${ }^{33}$ It is not known when this part was established, but it is clear the Jesuits invested 4,00o taels of silver to purchase gold in China and exchange it in Japan every year.

Ceramics ranging in quality from everyday commodities to luxury goods made up a total of 20,0oo pieces. Selling prices in Japan were about two to three times the purchase prices and differed significantly according to the product's quality. There was a twelve- to fifteen-fold difference between ten pieces of commodity ceramics at 0.1 tael and ten pieces of luxury ceramics at $1.2-1.5$ taels.

Plants growing wild in China, such as rhubarb, liquorice, and Smilax glabra (or tufuling, a component of Chinese herbal medicine), had quite a high profit ratio that could reach 400 percent. Smilax glabra was traded at especially high prices, so the Capitão-mór was allowed to treat it preferentially in Macao. ${ }^{34}$ Concerning sugar, the demand for brown sugar was higher than that for white among the Japanese; its profit ratio could reach goo percent. This was because sugar was used not primarily as food but as medicine, and there was great demand for it.

32 "The regulation of the Procurador of Japan residing in China. The visitor Francesco Pasio gave this regulation here when he came to Japan." Kōichirō Takase, Iesus-kai to Nippon [The Society of Jesus and Japan], trans. and notes, vol. 1 (Tokyo: Iwanami Shoten, 1981), 608.

33 Kōichirō Takase, "Kirishitan Kyōkai no Zaimu Tantō Padre" [Father Procurador of the Kirishitan Church], in Kirishitan Jidai no Kenkyū [Study on the Kirishitan Period] (Tokyo: Iwanami Shoten, 1977); Takase, "Kirishitan Kyōkai no Macao Chūzai Zaimu Tantō Padre" [Father Procurador of the Kirishitan Church in Macao], in Kirishitan Jidai Taigai Kankei no Kenkyū [Study on the External Relations in the Kirishitan Period] (Tokyo: Yoshikawa Kōbunkan, 1994).

See Chapter 5 . 


\begin{tabular}{|c|c|c|}
\hline Product & Price in Guangzhou & Notes \\
\hline Gold (superior) & silver 7 taels/tael & \\
\hline Musk & 8 taels/cate & \\
\hline Raw silk & 8o tael/pico & \\
\hline Twisted yarn made in Nanjing & 130 taels/pico & \\
\hline Damask roll (standard) & 7 taels/roll & Total length 14 vara \\
\hline Damask roll (superior) & 12-15 taels/roll & Total length 16 vara \\
\hline Taffeta roll made in Nanjing & $2.5^{-3}$ taels $/$ roll & Total length 12 côvado \\
\hline Silk fabric roll & 1.3 taels/roll & Total length 10 vara \\
\hline Cotton yarn & 8 taels/pico & \\
\hline Shawl with luxury silk & $3 \cdot 5^{-4}$ taels/piece & \\
\hline Net type shawl for women & $0.4-0.5$ taels $/$ piece & \\
\hline Cinnabar & 40 taels/pico & \\
\hline Copper & $7-8$ taels/pico & \\
\hline Brass & $7-8$ taels/pico & \\
\hline Quicksilver & 40 taels/pico & \\
\hline Wire & 8 mace/pico & \\
\hline Iron & 2 taels/pico & \\
\hline Refined iron & 2.5 taels/pico & \\
\hline Cinnabar sand (superior) & 7 taels/cate & \\
\hline Flake white & $2.5^{-3}$ taels/pico & \\
\hline Ceramics (superior) & 1.2 taels/10 pieces & \\
\hline High grade plate & 1.5 taels/10 pieces & \\
\hline High grade large plate & 0.3 taels/piece & \\
\hline Ceramics (standard) & 0.15 taels/10 pieces & \\
\hline Wheat & O.4 taels/pico & \\
\hline Wheat flour & o.8 taels/pico & 1.2 taels/pico (Мacao) \\
\hline Cow & & 4 taels/head \\
\hline Pig & 1.5 taels/pico & $2-3$ taels/head \\
\hline Hen & 2 taels/pico & \\
\hline Salted fish & 2 taels/pico & \\
\hline Fresh fish & 1 condrin/cate & \\
\hline (white) Sugar standard & $1.5^{-2}$ taels/pico & \\
\hline (white) Sugar superior & $2.5^{-3}$ taels/pico & \\
\hline Kapur & 10 taels/pico & \\
\hline Cinnamon & 3 taels/pico & \\
\hline Rhubarb & $2-3$ taels/pico & \\
\hline Liquorice & 2.5 taels/pico & \\
\hline Smilax glabra & o.8-1 taels/pico & \\
\hline
\end{tabular}




\subsection{Chinese Commodities for the Indian Market}

The imported volume of white yarn for India was 1,0oo picos, greater than the volume for Japan. The profit ratio was 15 o percent, thus 6 o percent higher than the rate for Japan. Twisted yarn was not contained in the list and the number of rolls of damask and taffeta bought was 10,000-12,000. This was equivalent to five times the number of silk fabric rolls for Japan. ${ }^{35}$ While goods described as "most of them are consumed by the local inhabitants" were silk textiles, gold, brass, and musk, one that was clearly mentioned as an exported good to Portugal was kapur (dryobalanops aromatica). Other goods destined for Europe passed through India, but they were likely consumed in India as well.

According to the Memorandum, places of collection were not limited to China but included Manila. As it is difficult to believe that high-quality silk fabric was mass-produced in Manila at this time, it seems that Chinese merchants from Zhangzhou (漳州) brought it to Manila. In other words, the Portuguese utilized Manila as a place in which to obtain Chinese goods more freely than in Guangzhou. While trade between Manila and Macao was prohibited under the union of Spain and Portugal by Felipe II (Philip II), restatements of these bans indicate they were not actually complied with. Especially around 1585 , when this Memorandum was written, the ban had not yet been issued and merchants in Macao traveled to Manila on their own ships in order to trade. ${ }^{36}$ Silk brought from there to India was supposed to be exported to Europe.

On this sailing route, gold was brought at three to four picos (weight 180-240 $\mathrm{kg}$ ), which was a much higher rate than in Japan. It could achieve a selling price in Goa up to 1.8-1.9 times higher than in Japan. The exchange ratio between gold and silver was one to thirteen. Exchanging gold into silver in India was more profitable than in Japan. Looking at other goods, sugar for instance had an import volume that was thirty times higher than in Japan. Crude drugs and minerals were also taken there in large amounts. This was proportional to the

35 Sixty-two rolls of damask were imported to Japan by a Dutch ship in 1615; thus even if the damask is not recorded in this Memorandum, it seems that damask was sometimes imported to Japan.

36 Lucio de Sousa, Early European Presence in China, Japan, the Philippines and South East Asia 1555-159o (Macao: Macau Foundation, 2010); Kōichirō Takase, Monsoon Monjo to Nippon:Jūnana Seiki Portugal Kōbunsho-shū [Monsoon Documents and Japan: Collection of Portuguese Archives in the Seventeenth Century] (Tokyo: Yagi Shoten, 2006), 70. The original source that Takase uses here is: António Bocarro, O livro das plantas de todas as fortalezas, cidades e povoações do estado da India Oriental, ed. Isabel Cid, vols. 1-2 (Lisbon: Casa da Moeda, 1992), 167-168. 
demand. The exception was quicksilver, used for plating gold and copper, ${ }^{37}$ which was more often imported and had a higher selling price in Japan. At that time the amalgam method for refining silver was used in silver mines but was not otherwise widely known.

\subsection{Commodities from India to China}

The types of loaded goods from Goa to India were comparatively limited. As the profit from gold exchange was greater than in Japan, a considerable quantity of silver was brought from India to China. How much is not clear, however, because the loaded volume was not recorded. Furthermore, daily commodities produced in Europe occupied a considerable proportion of the total. It was said that daily commodities such as wine and olive oil brought from afar were sometimes sold below cost. These goods were considered as not for onward selling but as gifts or for personal consumption by the Portuguese and Spanish.

So far I have analyzed trade between China and India and compared it with trade between China and Japan. As a result the trade between China and India has been proved to have been larger in scale and in profit ratio. The quantities of the major products, such as raw silk, rolls of cloth, and gold, exceeded those to Japan. India also paid more in silver. The exchange rate of gold to silver was one to 8.3 in Japan but one to more than ten in India. Profits from the gold trade in India were therefore greater even if the trade quantity remained the same. A report about forts and cities in Portuguese India by António Bocarro illustrates this point: ${ }^{38}$

The route from Goa to China, except the route to the (Portuguese) Kingdom, was the richest and most valuable in the (Portuguese India) Territory. The first $n a u^{39}$ was called the "silver nau". [...] Today, people make an effort and try to load even 300-40o candim (ca. 68-91 tons) in one galleon. ${ }^{40}$

According to a commonly accepted theory, the amalgam method was introduced in the 17 th century when contacts between Manila had been established. Akio Okada, "Kinsei Shoki ni okeru Shuyō naru Yunyū Busshi ni tsuite" [Major Imports in the Early Stage of the Early Modern Period], in Nichi-Ō Kōshō to Namban Bōeki [Negotiations between Japan and Europe and the Namban Trade], Okada Akio Chosaku-shū [Works of Okada Akio], vol. 3 (Kyoto: Shibunkaku Shuppan, 1983), 10-18.

38 Bocarro, O livro das plantas de todas as fortalezas, cidades, e povoações do Estado da Índia Oriental.

39 Carrack.

40 Takase, Monsoon Monjo to Nippon, 167-168. 
India was not the main silver production area at this time. ${ }^{41}$ It is possible that the silver mentioned was brought instead from the Americas to Europe and then taken on to India. Trade between China and India was declining when the voc appeared in the China seas, coming from the Indian Ocean area to Southeast Asia in the 17th century. The Dutch fought several battles with their Portuguese and Spanish rivals. ${ }^{42}$ While the "silver ships" between China and India were declining in number, those on other routes were increasing. In other words, since the 1570s the galleon trade between Acapulco and Manila had developed, and coincidentally the silver trade via India in Asia weakened. Evidence for this relationship is hard to find, so it is difficult to calculate the exact impact the opening of the Manila-New World route had on Portuguese trade within Asia. We should consider that the Portuguese in Macao monopolized the silver trade with Japan, where large quantities were produced. Compared with the Spanish, who lacked further ports, the Portuguese used their networks of local port cities in Asia to collect products that were needed in China.

\subsection{Products from Various Regions across Asia}

Most of the commodities transported from China to Japan were produced in China. Though products made in South Asia and Southeast Asia were not on the list, products such as agalloch, sandal wood, and Tonkin raw silk from Cochinchina, agalloch and aloes wood from Cambay, tin and pepper traded in Manila, kapur from Borneo, clove from the Maluku Islands, and raw silk and silk fabric from Manila were commonly traded goods and were carried by redseal ships from various places. ${ }^{43}$ Macao merchant ships also were keen to bring them to Japan.

I have summarized the products from Siam that we can define most precisely in Table 2.3. I will compare them with the load of Portuguese, red-seal and Dutch ships. While the Portuguese records are from the late 16th century, the records of red-seal and Dutch ships are from the late 17th century.

Commonly traded goods were sappan wood, lead, areca nut products, and turmeric products. Silver, musket, and benzoin were added to these items for Portuguese ships during the 16th century. Deer skin, shark skin, agalloch, and tin were listed for red-seal ships and Dutch ships in the 17th century. Among others, deer skin and shark skin seem to have been as important as sappan wood. It is unclear why they were not listed in the trade records of the

\footnotetext{
41 Om Prakash, Precious Metals and Commerce (London: Routledge, 1994).

42 Takase, Monsoon Monjo to Nippon, 167-168.

43 Iwao, Shuin-sen Bōeki-shi no Kenkyū, 288-289.
} 


\section{Place of Production Products}

$\begin{array}{ll}\text { Malacca } & \text { Clove, nutmeg, mace, tin, turtle shell, pearl } \\ \text { Ceylon } & \text { Cinnamon, diamonds, precious stones } \\ \text { Bengal } & \text { Cotton cloth, sugar, precious stones, rice } \\ \text { Mozambique } & \text { Ivory, sappan wood } \\ \text { Hormuz } & \text { Arabian horses, brass, silver larin coin, dates, camel fabric, } \\ & \text { rose water, Venetian gold coin } \\ \text { Pegu } & \text { Rack (red dye from coccid) } \\ \text { Siam } & \text { Silver, musket, benzoin, turmeric oil, coconut oil, sappan } \\ & \text { wood, lead, rice } \\ \text { Cochinchina } & \text { Agalloch, aloes wood, silver, lead, pepper, raw silk } \\ \text { Champa } & \text { Agalloch, aloes wood (superior to that from Cochinchina), } \\ \text { black wood for chopsticks } \\ \text { Timbay } & \text { Frankincense made in Dhufar } \\ \text { Borneo } & \text { Sandalwood } \\ \text { Maluku Islands } & \text { Kapur, furniture made of kapur } \\ \text { Banda } & \text { Some kinds of clove } \\ \text { Japan } & \text { Nutmeg, mace, feathers from rare herons } \\ \text { Sunda } & \text { Silver, tuna, sword, haft } \\ \text { Manila } & \text { Various goods } \\ & \text { Cotton fabric, silk fabric made in China (damask, taffeta, } \\ & \text { twisted yarn, sleaved raw silk), dish, gold } \\ \end{array}$

Portuguese ships. Nagazumi Yoko explains concerning deer skins that "they might be imported in a large scale from the Philippines from the end of the 16th century until the beginning of the 17th century. Later they were imported mainly from Siam and Taiwan." 44 Antonio Morga, who was a colonial official in the Philippines, wrote Sucesos de las Islas Filipinas (Events in the Philippine Isles), in which he gathered information about trade and related subjects that he garnered during his stay in the Philippines from 1595 to 16o3. He wrote:

These ships [from Japan] go back to Japan in the season of the southwest wind in June and July. They bring raw silks from China, gold, deer skin,

44 Yōko Nagazumi, Shuin-sen [Red-seal Ship] (Tokyo: Yoshikawa Kōbunkan, 2001), 108. 


\begin{tabular}{|c|c|c|}
\hline Source & Period & Products \\
\hline $\begin{array}{l}\text { Memorandum of Trading } \\
\text { Goods by Portuguese Ships }\end{array}$ & $\begin{array}{l}\text { Assumed } \\
15^{8} 5^{-1600}\end{array}$ & $\begin{array}{l}\text { Silver, musket, benzoin, turmeric oil, } \\
\text { coconut oil, sappan wood, lead, rice }\end{array}$ \\
\hline $\begin{array}{l}\text { List of import/export goods } \\
\text { of red-seal ships according } \\
\text { to regions }\end{array}$ & $1603-33$ & $\begin{array}{l}\text { Sappan wood, deer skin, shark skin, } \\
\text { buffalo horn, lead, tin, kapur, dragon's } \\
\text { blood, calico, striped cotton cloth, } \\
\text { ivory, cane, coral pearl, agalloch }\end{array}$ \\
\hline $\begin{array}{l}\text { List of Siam products } \\
\text { imported to Japan market } \\
\text { by Dutch ships }\end{array}$ & 1634 & $\begin{array}{l}\text { Deer skin, shark skin, sappan wood, } \\
\text { extra quality agalloch, lead, tin, } \\
\text { Cambodian walnut, yellow salve, dried } \\
\text { areca nut, rattans, ivory, brown sugar, } \\
\text { black lacquer }\end{array}$ \\
\hline
\end{tabular}

sappan wood for dye, honey, bees wax, coconut liquor, wine from Castilla, zibet, pot for tea, glass, cloth from Manila and rare goods from Spain back home. ${ }^{45}$

In other words, the Japanese and Portuguese did not import deer skin from Siam but from Manila at the end of the 16th century. We can suppose this was the reason these skins were not loaded on many Portuguese ships. Morga also lists products brought by the Chinese from Zhangzhou, Fuzhou (福州), and Guangzhou, as shown in Table $2.4^{46}$

This table shows that items brought by the Chinese to Manila were similar to those brought by the Portuguese from China to India. We learn from this that almost every item was sent to Europe and that the goods traded by Macao and Chinese merchants in Zhangzhou, Fuzhou, and Guangzhou were almost the same. Furthermore, we should pay attention to the fact that many of these products were not only from China but also from Southeast Asia and the wider region. It is also clear that the Spanish bought ginseng from the Chinese not for trade in Europe but in Japan.

45 Morga, Philippine Shotō-shi, 392.

46 Ibid., 388. 


\begin{tabular}{ll}
\hline Category & Products \\
\hline Fabric & $\begin{array}{l}\text { Raw silk, various colored pure silk, velvet, damask, silk } \\
\text { fabric, satin, taffeta, grogram, picot, linen cloth, white } \\
\text { cotton cloth, kanga (black cotton cloth), mantle }\end{array}$ \\
\hline Luxury grocery items & Musk, benzoin \\
\hline Furniture and craftwork & $\begin{array}{l}\text { Pottery, ivory, canopy, bed cover, veil for canopy, } \\
\text { table cloth, cushion, carpet, harness, hand mirror, } \\
\text { small box, desk, bed, tab le, chair, bench, thread, } \\
\text { string }\end{array}$ \\
\hline Pearl, ruby, sapphire, crystal, copper, iron, tin, lead, \\
niter, gunpowder \\
Foods & $\begin{array}{l}\text { Pepper, sugaring (orange, peach, ginseng), pear, } \\
\text { nutmeg, fruits in general, salted pork, dried meat, } \\
\text { chicken, various kinds of spices }\end{array}$ \\
\hline Animals (for domestic & $\begin{array}{l}\text { Buffo, heron, horse, donkey, mule, ornamental } \\
\text { birds }\end{array}$ \\
\hline use/ornamental)
\end{tabular}

\subsection{Japanese Commodities for the Chinese Market}

Import and export items and prices were on the list of trades between China and India, as well as between Japan and China. A list of goods and prices from China was also provided in detail, but there is no list of goods and prices for the trade from Japan to China. "Trade goods and places of production of the Portuguese" just mentions the production of silver, tuna, swords, and haft.

An English sailor Ralph Fitch, who traveled from the Indian Ocean to the Chinese Sea between 1585 and 1591, recorded that "when the Portuguese sail from Macao to Japan, they import a lot of raw silk, gold, musk and porcelain but export only silver." ${ }^{\prime 7}$ This description fits the Memorandum and shows that there was no main product except silver, which was paid by Japanese. On the other side, various products were imported from China to Japan. Furthermore, the correspondence between the descriptions in the Memorandum and Fitch's record may show that the trade situation described in the Memorandum was after all true for the period. 
Morga, whom I have already quoted, writes about Japanese and Portuguese ships sailing from Japan to Manila as follows:

Every year Japanese and Portuguese merchants sail from the Nagasaki port from Japan and travel to this island riding on the northern winds in the end of October and around March. They anchor in Manila by following the same procedure. Their main goods are wheat of a very good quality which is much needed in Manila. They also import high-priced dried meat, beautiful colored silk textile, fold screens with a flamed decor and oil painting with gold leaves, various kinds of blades, armors, javelins, swords and other weapons with beautiful crafts, writing desks, boxes, small lacquered wood boxes and put patterns, good looking accessories at a moderate price, fresh pairs with very excellent quality, barrels and tubs of good quality salted tuna, larks in cages called Shinbarol with a very good voice and more. [...] Most of them are consumed within the island and some are goods destined for New Spain. The payment is made with real silver coins. However, as silver is produced in Japan, they don't need it as much as the Chinese. They even usually bring a lot of silver plates themselves to sell at a comparatively low price. ${ }^{48}$

We can see from this description that in addition to silver goods brought from Japan to Manila the products were mostly food, craftwork, and swords. The main product exported from Japan was silver, and no other products could expect to achieve such high profits. Furthermore, this proves that Japanese ships and Portuguese ships competed against each other as they brought similar products from Japan to Manila in the same period (1595-1603).

\section{Customs and Freight Rate}

The Memorandum touches on matters of customs, freight rate and the consideration for the Capitão-mór in various places. Now I will further analyze this after taking a look at the recent research from Takase Kōichirō on the matter. ${ }^{49}$ Takase quotes many authorities from different periods concerning the customs and freight rate of Portuguese ships' trade between Japan and Macao and also the reward to the Capitão-mór that took place from time to time.

\footnotetext{
48 Morga, Philippine Shotō-shi, 391-392.

49 Takase, Monsoon Monjo to Nippon, 70-8o.
} 
In the latter half of the 16th century, when private merchant ships came from Macao to Japan every year, the Capitão-mór could not monopolize trade in Japan. Private merchants came to Japan with their own ships, at least until around $1610 .{ }^{50} \mathrm{I}$ assume that private merchant ships from Macao ceased to go to Japan because of the obligation to receive the red-seal ships that was issued by the Tokugawa Shogunate and also the Madre de Deus incident in 1610, when the Capitão-mór ship of André Pessoa was attacked by the governor's army of Nagasaki and Arima Harunobu (有馬晴信). ${ }^{51}$ Pessoa finally blew up himself and his ship in Nagasaki's bay. Following this incident, the Capitãomór trade changed its structure and began to use a group of several smaller ships (galliots) in order to reduce the risk of using a single large ship (nau). Private merchant ships mostly vanished because their owners officially joined the trade with Japan by offering their ships to the Capitão-mór. This process is an important turning point in the history of the Namban trade, which will be addressed later.

\subsection{Capitão-mór Income and Freight Charges}

After 1556, the authorization of trade with Japan began to be invested by the Portuguese king in only one person according to his military achievement or if he paid money for it (the Capitão-mór system). ${ }^{52}$ The benefit of this authorization was not the income from goods but the collection of "freight charge," a certain ratio of prices of goods, from the Society of Jesus, the Santa Casa da Misericórdia, for example, and organizations in Macao. ${ }^{53}$ The chief

50 Kōichirō Takase, "Kirishitan Jidai ni okeru 'Kyōshō"' ["Religious-Merchants" in the Kirishi$\tan$ Period], in Kirishitan Jidai Taigai Kankei no Kenkyū.

$5^{1} \quad$ The bases for my assumption are (1) there is no record of private ships that went to Japan after 1610 in the Portuguese documents; (2) the private ship of a wealthy merchant that entered the port of Nagasaki in 16og received something like a red-seal certificate (see Chapter 6); and (3) in 1613, when the Capitão-mór from Macao arrived in Japan for the first time after the incident he went to the Edo court where he received a red-seal certificate to cross the sea. But this is just a hypothesis at this time.

Okamoto Yoshitomo thinks the Capitão-mór system for navigation to Japan was regulated, both in name and reality, after 1556 with Dom Francisco Mascarenhas. Before that date, according to him, private ships reached Japan several times a year. Okamoto, 16 Seiki Nichi-Ō Kōtsū-shi no Kenkyū, 28o-281.

53 Takase, Monsoon Monjo to Nippon, 77. The original source that Takase uses here is: Unknown author, 1582. Livro das cidaded, e fortalezas que a coroa de Portugal tem nas partes da India, e das capitanias, e mais cargos que nelas há, e da importância delles. This book is transcribed by Francisco Paulo Mendes da Luz and published by Centro de Estudos Historicos Ultramarinos in 1960 . 
merchant (feitor do povo) was entrusted with selling these goods in Japan and calculating the profits.

According to Takase Kōichirō, 2,ooo picos of raw silk were loaded into the ship of the Capitão-mór destined for Japan every year, and the cargo owners had to pay 10 percent of the net price of any loaded goods as freight to the Capitão-mór. ${ }^{54}$ Manuel Dias, a Jesuit, records that they had to pay for 2,00o picos of raw silk loaded even if the actual amount loaded was less. ${ }^{55}$

The Memorandum states this more precisely, and we can conclude the basic incomes of the Capitão-mór as the following: (1) the freight charge of raw silk, which was 10 percent of the net price; (2) 500 taels from cargo owners with other goods; and (3) the equivalent of sales of sixty picos of excellent quality raw silk sold in a package deal. Calculating the basic income of the Capitãomór from one passage of the Memorandum, it amounted to 16,000 ((80 taels per 1 pico of raw silk $\times 0.1) \times 2,000)+9$, O0o $(15$ o taels $\times 6$ o picos $)+5$, ,0oo (estimating ten owners of other goods) equal to a total of 30,0oo taels. However, this is not correct, as the net and selling prices of raw silk differed from time to time, and the number of owners of other goods cannot be identified. Furthermore, Smilax glabra was monopolized by the Capitão-mór and its sales profits were also expected to make up part of his income. ${ }^{56}$

António Bocarro states in his record, written in about 1635, that 1o percent of the total sales from trade were posted into the safe at Macao and that less than a tenth of this was paid to the Capitão-mór as his consideration. ${ }^{57}$ The change in the privileged consideration system shown in this record seems to be related to the considerable changes in the trading system in Japan. As Chapter 4 will show, the city of Macao owed a huge debt to the Japanese in the 163 os and thus suspended the Capitão-mór system after $1634{ }^{58}$ The rigging of the ship and the acquisition of staff in 1635 were funded by the public property (royal treasury) saved in Macao, and the experienced Capitão-mór was elected to be sent to Japan under paid employment. The city of Macao tried to improve the debt situation by reducing the necessary costs to a minimum. We have to consider

\footnotetext{
54 Ibid., $72-73$.

55 Álvarez Taladriz, "Un documento de 1610 sobre el contrato de armação de la nao de trato entre Macao y Nagasaki," Tenri Daigaku Gakuhō [Bulletin of Tenri University] 11, no. 1 (1959): 6. The original source transcribed here is: A report written by Manuel Dias dated April, 18th, 1610 in ARSI, Jap. Sin. 14-II, fl. 341-341v.

56 Takase, Monsoon Monjo to Nippon, 70.

57 Ibid., 72.

$5^{8}$ Boxer, The Great Ship from Amacon, 140-141. The Capitão-mór of this year was Lopo Sarmento de Carvalho. He, too, was a converted Jewish merchant.
} 
therefore that both the meaning and the income of the Capitão-mór in terms of Japanese trade saw significant change after 1635 .

\subsection{Customs}

Malacca, Ceylon, and Goa were mentioned in the Memorandum as the places where Portuguese ships paid customs on the Asian trade route. Of this, 7.5 percent of the total amount of goods was paid in Malacca, but there was no trade there. Does this mean that trading ships of the Capitão-mór only paid customs duties and left after having supplied their ships and waited for the right wind? This was indeed the order of the Viceroy of Portuguese India. What really happened is shown in the following statement:

We paid 8 percent of the total goods as customs at the custom office when we arrived at Malacca. On our departure, we don't pay anything. However, to prevent the Capitão-mór [in Malacca] from damaging travels to China for spices, we cannot bring any spices or other goods from there [Malacca] to China under the edict of the past Viceroy. We had several discussions with the Capitão-mór [in Malacca]. Those [who authorized the voyage from China to Japan] bought the aforementioned allowance for spice travel from them [the Capitão-mór of Malacca] to bring [spices] to China. They are the main products with large values there [China]. ${ }^{59}$

This source dates from 1582 , close, if I am correct in my dating, to the time described in the Memorandum. It is clear that the rights pertaining to the spice trade lay basically with the captains in Malacca. But the Capitão-mór traveling from India to China and engaged in trade between Japan and Malacca bought the rights. They brought spices directly from Malacca to China because spices (mostly pepper) were sold at a high price in China.

In other words, the line in the Memorandum that states "in Malacca, no item is sold nor discharged" was repeating the official rule. Yet in reality, the buying and selling of trading rights among the captains (capitão) broke this rule. The Memorandum contains further information about payment of 8.5 percent of the loaded goods at arrival and departure in Goa, the payment of

59 Record about the cities and the fortresses in India possessed by the Portuguese court, about the Capitão-mór and other offices in these cities and fortresses and the expenditure for them (1582). Cited from Takase, Monsoon Monjo to Nippon, 76-77. For the original text in Portuguese, see Francisco Paulo Mendes da Luz (ed.), "Livro das cidades, e fortalezas, que a Coroa de Portugal tem nas partes da Índia, e das capitanias, e mais cargos que nelas ha, e da importância delles," Studia 6 (196o): 351-363. 
2,000-3,000 cruzados by forcibly taking under tow ships that sailed in the sea around Ceylon, and so on.

The Memorandum does not state that customs were collected in Macao as the king's profit. The aforementioned record by Manuel Dias from 1610 states that there was no customs system to profit the Portuguese king, but that the city authorities of Macao collected 2-4 percent of the loaded goods from ships that sailed into Macao as customs duties. ${ }^{60}$ This was called cardeirão and was collected as common property to maintain the city. However, Bocarro recorded for 1635 that the customs duties that became the profit of the Portuguese king were 10 percent of the total trade profit. ${ }^{61}$ We should consider therefore that some changes to the customs system in Macao were made between 1610 and 1635. This seems to be related to the changed relations between Macao and Portuguese India in the 1620s, which I will discuss in more depth in Chapters 4 and 5 . Chinese Authorities

From 1620 onwards, customs duties pertaining to the Portuguese India trade were collected in Macao. In fact, the Portuguese paid "groundage" to the Guangzhou authority after they entered their contract of settlement.

The Memorandum says the amount of port dues depended only on the capacity of a ship regardless of whether it was loaded or not. We already know the Portuguese paid land taxes to the Chinese authority, ${ }^{62}$ but other taxes have not been researched until now. ${ }^{63}$ However, determining who had a right to collect taxes relating to the port services will help to define to whom the land belonged.

In 1556 Dominican friar Gaspar da Cruz stayed around Guangzhou. He recorded that the Chinese authority measured the total length of ships that

6o Takase, Monsoon Monjo to Nippon, 73; Taladriz, "Un documento de 1610 sobre el contrato de armação de la nao de trato entre Macao y Nagasaki," 7 .

61 Takase, Monsoon Monjo to Nippon, 71-72.

62 According to a commonly accepted theory, the land taxes in Macao were 5 oo taels per year, but this was actually the amount after 1740. It is said that the original amount of the land taxes was 1,00o taels, and 6oo taels after 1691, then 500 taels after about 1740. Jin'ichi Yano, Shina Kindai Gaikoku Kankei Kenkyū [Study on the External Relations of China] (Tokyo: Kōbundō, 1928), 367-377.

63 Yano, Shina Gaikoku Kankei Kenkyū, 376-377. 
sailed into Guangzhou and collected groundage from them. ${ }^{64}$ Concerning these port dues, the story of Omura Sumitada (大村純忠) is a well-known example. He entrusted the collection of anchorage fees to the Jesuits when he donated Nagasaki to them in 1580. The groundage at Nagasaki was 1,00o ducats per ship. ${ }^{65}$ This case demonstrates the general rule that the groundage was paid to the landowner.

From the Memorandum we know that "even if inhabitant in Macao," in other words if one were also a Portuguese trader living in Macao, one had to pay the groundage. This payment was apparently made to the Chinese authority. Linschoten, a Dutchman staying in Portuguese India, observed in detail how these dues were collected by the Chinese authority from the Portuguese:

Portuguese live together with local Chinese in Macao city and its islands. They do business with people in Guangzhou. But all products from Guangzhou are brought [to Macao] by local Chinese. Portuguese are not allowed to visit Guangzhou. For this reason ships can come travel from India to Macao. When ships come from India, Mandarins [authorities] and officials in Macao measure the width and length of the ships. They issue a bill and collect the groundage. Once the groundage is paid, they can load goods as they wished and no more tax payment nor confiscation of goods will happen. Portuguese are allowed to elect one Portuguese functioning as a representative. He is sent to Guangzhou to buy what they want. ${ }^{66}$

Linschoten stayed in Portuguese India from 1583 to 1588 . After his return he published an account of his own experience and the information he had gained about the Dutch foray into Asia. His stay was close in time to the possible date when the Memorandum was written, and the works share some points. In other words, it is clear the Portuguese paid not only land taxes but also groundage to the Chinese authority after their settlement in Macao. As

64 Gaspar da Cruz, Chügoku-shi [Tractado das cousas da China], trans. Hino Hiroshi (Tokyo: Kōdan-sha, 2002; first published Tokyo: Shin Jinbutsu Ōrai-sha, 1996); Charles Ralph Boxer (ed.), South China in the 16th Century (Bangkok: Orchid Press, 2004; first published 1953).

65 Kōichirō Takase, "Kirishitan Kyōkai no Keizai Kiban wo meguru Naibu no Rongi" [Internal Discussion about the Economic Base of the Kirishitan Church], in Kirishitan Jidai no Kenkyū, 423-426.

66 Jan Huyghen van Linschoten, Tōhō Annai-ki [Itinerario/Discours of Voyages into ye East \& West Indies], trans. and notes Iwao Seiichi et al. (Tokyo: Iwanami Shoten, 1968), 241. 
the latter amount was 3,000-4,00o taels per ship with a load of 300 tons, its relative importance compared with the 500 taels of land tax is clear.

Navarrete, a Dominican who stayed temporarily in Macao in the middle of the $17^{\text {th }}$ century, wrote about the groundage as follows:

Macao has so far paid the land tax for building houses and churches and the groundage for ships to Chinese authority. When a ship arrives, the Chinese authority comes from its Metropolis (Guangzhou) to measure the ship's capacity and collect a tax responding to the quantities of its load. When the ship departs, they measure its size again and collect customs. The method of measuring changes every year. ${ }^{67}$

Land tax, groundage, and customs upon arrival and departure were paid to the Chinese authority in Macao. This method of collecting taxes was similar to the customs system used by the Portuguese in Goa. Yet it becomes obvious that the Chinese authorities allowed the Portuguese to settle and live in Macao. The Chinese overlooked the Portuguese settlements while imposing large land taxes and groundage on them. Navarrete explains the differences between Macao and Manila as follows:

Macao has flourished from trades with Manila and Japan and become very rich. However, Macao cannot compare with Manila and I cannot find any similarities between these two cities. I have found many different points in many ways between these two cities. These differences are similar to those between Madrid and Vallecas [they are similar to London and Hammersmith], 68 and while people in Manila are free, people in Macao are slaves [of China]. ${ }^{69}$

In this description the main characteristics of Macao are captured from within the framework of European colonialism. Macao's differences are illustrated through a comparison with Manila in Spain and the view of the people in Macao as Chinese slaves.

67 Dominick Navarrete [Domingo Fernández Navarrete], An Account of the Empire of China, Historical, Political, Moral and Religious, Chapter XIII (London, 1703), 261.

68 Vallecas is a small neighborhood in the suburbs of Madrid. Hammersmith is now a district in the western part of London. It was formerly a small village in the suburbs of London.

69 Navarrete, An Account of the Empire of China. 
Another kind of tax problem occurred in the 1620 . Macao sustained serious damage from a military attack by the voc fleet in 1622 . To remedy this situation, the resident administration officer in charge of military defense and control of the citizens, the Captain General (Capitão-geral), was sent from the viceroy's office of Portuguese India to Macao. The first Governor, Dom Francisco Mascarenhas, began to consolidate the military functions and the administrative structure. He further improved the economy during his term of office. As part of this effort he tried to build a fort and install a cannon factory to strengthen the military. The construction of this fort irritated the Ming authorities that oversaw the Portuguese settlement in Macao. The Haitao-fushi (海道副使) of Guangdong province arrived in Macao in May 1625 to investigate the matter. He indicated that 22,00o taels as tribute divided into two portions per year was to be collected under "the order of the Tutan (都堂, governor), ${ }^{, 70}$ for a permit to build a fort. Trading was to be allowed between Macao and Guangzhou after payment was confirmed. This was repeated every time a payment was made. ${ }^{71}$ Further regulations stated that the Portuguese would not be allowed to have four ocean defense ships anchored at the same time in Macao. The amount of rice that was brought from Guangzhou to Macao every month was to be halved. ${ }^{72}$ At this time China was undergoing political change from the Ming to the Qing dynasty. The Ming seemed to demand from the Portuguese as much tribute as they possibly could.

The Portuguese government in Goa deemed Macao to be a part of its domain and the Chinese authorities deemed Macao to be a place where the Portuguese were allowed to stay after offering their tribute and obedience. We can say, therefore, that at this time Macao was probably already acting according to a "two systems in one country" agenda.

70 Governor of a province. Under this office, there were Buzhengshi (布政使, Provincial Treasurer), Anchashi (按察使, Provincial Judge), Haitao-fushi (海道副使, Provincial Commander) and BeiwoTuchihhui (備倭都指揮, Commander of the Coast Guard). 
TABLE 2.5 Price list of the commodity in the Portuguese intra-Asian trade of the 16 th century

\begin{tabular}{|c|c|c|c|}
\hline Origin & Commodity & Quantity & Price in Goa \\
\hline \multicolumn{4}{|l|}{$\begin{array}{l}\text { China } \Rightarrow \text { Japan } \\
\text { route }\end{array}$} \\
\hline China & raw silk & $500 \sim 600$ picos & \\
\hline China/Manila & $\begin{array}{l}\text { twisted thread } \\
\text { (fine) }\end{array}$ & $400 \sim 500$ picos & \\
\hline China/Manila & $\begin{array}{l}\text { twsited thread } \\
\text { average }\end{array}$ & included above & \\
\hline China/Manila & darc thread & included above & \\
\hline China/Manila & $\begin{array}{l}\text { silk textile } \\
\text { embroidered }\end{array}$ & $1700 \sim 2100$ piece & \\
\hline China & gold (average) & $3000 \sim 4000$ taeis & \\
\hline China & gold (fine) & included above & \\
\hline China & musk(average) & 2 picos & \\
\hline China & musk(fine) & included above & \\
\hline China & white ceruse & 500 picos & \\
\hline China/Manila & cotton thread & $200 \sim_{300}$ picos & \\
\hline China/Manila & $\begin{array}{l}\text { black cotton } \\
\text { textile }\end{array}$ & 3000 pieces & \\
\hline China/Manila & $\begin{array}{l}\text { black mixed } \\
\text { cotton textile with } \\
\text { silk }\end{array}$ & included above & \\
\hline China/Manila & $\begin{array}{l}\text { white cotton } \\
\text { textile }\end{array}$ & included above & \\
\hline
\end{tabular}




$\begin{array}{llll}\text { Price in Canton } & \begin{array}{l}\text { Price in } \\ \text { Macao }\end{array} & \begin{array}{l}\text { Price in } \\ \text { Japan }\end{array} & \text { Profit ratio }\end{array}$ Note

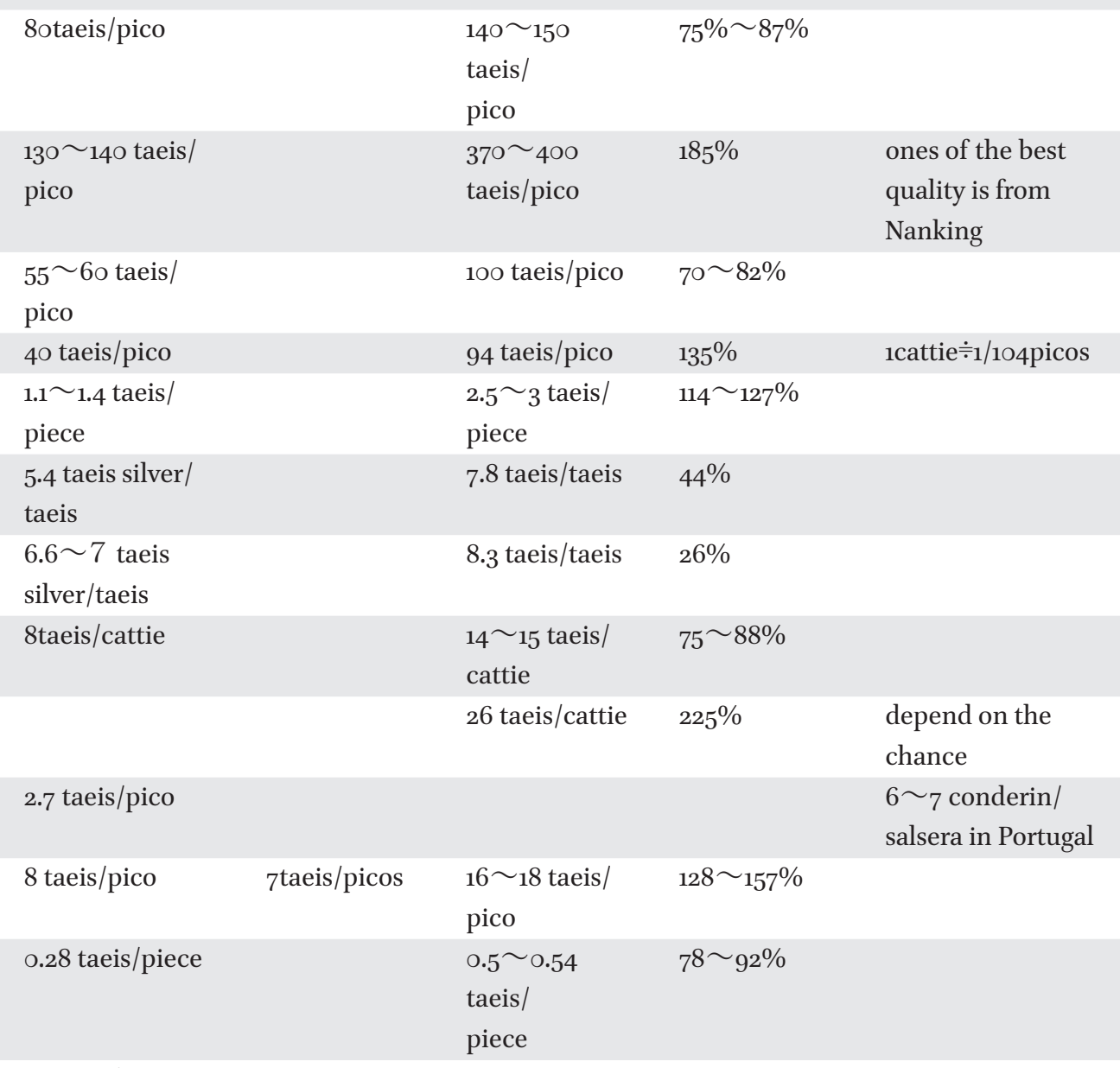

1.3 taeis/pico

$\begin{array}{ll}0.12 \text { taeis/piece } & 0.23 \sim 0.24 \quad 92 \sim_{100 \%} \\ & \text { taeis } / \\ & \text { piece }\end{array}$


TABLE 2.5 Price list of the commodity in the Portuguese intra-Asian trade of the 16 th century (cont.)

\begin{tabular}{|c|c|c|c|}
\hline Origin & Commodity & Quantity & Price in Goa \\
\hline China/Manila & $\begin{array}{l}\text { colored cotton } \\
\text { textile }\end{array}$ & included above & \\
\hline China & quicksilver & $\begin{array}{l}150 \sim 200 \\
\text { picos/30o picos }\end{array}$ & \\
\hline Siam & lead & 2000 picos & \\
\hline China & China root & $500 \sim 600$ picos & \\
\hline China & $\begin{array}{l}\text { ceramic and } \\
\text { porcelin(fine) }\end{array}$ & 20000 pieces & \\
\hline China & $\begin{array}{l}\text { ceramic and } \\
\text { porcelin(average) }\end{array}$ & included above & \\
\hline China & $\begin{array}{l}\text { ceramic and } \\
\text { porcelin(inferior) }\end{array}$ & included above & \\
\hline China & rhubarb & 100 picos & \\
\hline China & liquorice & 150 picos & \\
\hline China & white sugar & $60 \sim 70$ picos & \\
\hline China & brown sugar & ${ }_{150} \sim 200$ picos & \\
\hline \multicolumn{4}{|l|}{$\begin{array}{l}\text { China } \Rightarrow \text { Goa } \\
\text { route }\end{array}$} \\
\hline China & $\begin{array}{l}\text { raw silk and } \\
\text { twisted thread }\end{array}$ & 1000 picos & $\begin{array}{l}200 \text { cruzados/ } \\
\text { picos }\end{array}$ \\
\hline China/Manila & silk damasc (fine) & $\begin{array}{l}10000 \sim \\
12000 \text { pieces }\end{array}$ & wide range \\
\hline China/Manila & $\begin{array}{l}\text { silk damasc } \\
\text { (excellent) }\end{array}$ & included above & wide range \\
\hline
\end{tabular}




\begin{tabular}{|c|c|c|c|c|}
\hline Price in Canton & $\begin{array}{l}\text { Price in } \\
\text { Macao }\end{array}$ & $\begin{array}{l}\text { Price in } \\
\text { Japan }\end{array}$ & Profit ratio & Note \\
\hline $\begin{array}{l}\text { 0.085 taeis/ } \\
\text { piece }\end{array}$ & & $\begin{array}{l}0.16 \sim 0.17 \\
\text { taeis/ } \\
\text { piece }\end{array}$ & $88 \sim_{100 \%}$ & \\
\hline \multirow[t]{2}{*}{40 taeis/pico } & $\begin{array}{l}43 \text { taeis/ } \\
\text { picos }\end{array}$ & $\begin{array}{l}90 \sim 92 \text { taeis/ } \\
\text { pico }\end{array}$ & $125 \sim 130 \%$ & \\
\hline & 3 taeis/picos & 6.4 taeis/pico & $113 \%$ & \\
\hline $\begin{array}{l}\text { o.8 } \sim_{1} \text { taeis } / \\
\text { pico }\end{array}$ & $\begin{array}{l}1 \sim 1.2 \text { taeis } / \\
\text { picos }\end{array}$ & $\begin{array}{l}4 \sim_{5} \text { taeis/ } \\
\text { pico }\end{array}$ & $400 \%$ & \\
\hline $\begin{array}{l}1.2 \sim 1.5 \text { taeis } / 10 \\
\text { pieces }\end{array}$ & & $\begin{array}{l}\text { wholesale } \\
\text { pricex } 2 \sim_{3}\end{array}$ & $100 \sim_{200} \%$ & $\begin{array}{l}1 \text { big and high } \\
\text { quality piece@15 } \\
\text { maces }\end{array}$ \\
\hline \multicolumn{5}{|l|}{$\begin{array}{l}1.5 \text { maces/10 } \\
\text { pieces }\end{array}$} \\
\hline \multicolumn{5}{|l|}{ 1real/1o pieces } \\
\hline 2.5 taeis/pico & & 5 taeis & $100 \%$ & \\
\hline 2.5 taeis/1pico & 3 taeis/picos & $\begin{array}{l}9 \sim 10 \text { taeis/ } \\
\text { pico }\end{array}$ & $260 \backsim 300 \%$ & \\
\hline \multirow[t]{2}{*}{$\begin{array}{l}1.5 \sim_{2} \\
\text { taeis/1pico }\end{array}$} & $\begin{array}{l}1.5 \text { taeis/ } \\
\text { picos }\end{array}$ & $\begin{array}{l}3 \sim 4.5 \text { taeis/ } \\
\text { pico }\end{array}$ & $100 \sim_{125} \%$ & $\begin{array}{l}\text { Japanese prefer } \\
\text { brown sugar }\end{array}$ \\
\hline & $\begin{array}{l}0.4 \sim \\
\text { o. } 6 \text { taeis/ } \\
\text { picos }\end{array}$ & $\begin{array}{l}4 \sim 6 \text { taeis/ } \\
\text { pico }\end{array}$ & $900 \%$ & \\
\hline 8o taeis/pico & & & $150 \%$ & 1cruzado $\doteqdot 1$ tael \\
\hline 5 taeis/piece & & & & $\begin{array}{l}\text { consumed in } \\
\text { India, ones have } \\
\text { 16varas as width@12 } \\
\sim_{15} \text { taeis/piece }\end{array}$ \\
\hline $6 \sim 7$ taeis/piece & & & & consumed in India \\
\hline
\end{tabular}


TABLE 2.5 Price list of the commodity in the Portuguese intra-Asian trade of the 16 th century (cont.)

\begin{tabular}{|c|c|c|c|}
\hline Origin & Commodity & Quantity & Price in Goa \\
\hline China/Manila & taffeta(fine) & included above & wide range \\
\hline China/Manila & taffeta(excellent) & included above & wide range \\
\hline China & gold & $3 \sim 4$ picos & $\begin{array}{l}\text { wholesale price } \\
\text { x } 1.8 \sim_{1.9}\end{array}$ \\
\hline China & brass & $500 \sim 600$ picos & $\begin{array}{l}\text { wholesale } \\
\text { pricex2 }\end{array}$ \\
\hline China & musk & $6 \sim 7$ picos & $\begin{array}{l}\text { more than } \\
\text { wholesale price } \\
\text { x } 2\end{array}$ \\
\hline China & quicksilver & 100 picos & $\begin{array}{l}\text { wholesale } \\
\text { pricexı.7 } \sim_{1.8}\end{array}$ \\
\hline China & cinnabar & 500 picos & $\begin{array}{l}\text { wholesale price } \\
\mathrm{x}_{1.7} \sim_{1.8}\end{array}$ \\
\hline China & white sugar & $\begin{array}{l}2000 \sim 3000 \\
\text { picos }\end{array}$ & $\begin{array}{l}\text { wholesale pricex } \\
2 \sim_{3}\end{array}$ \\
\hline China & China root & $1000 \sim 2000$ picos & $\begin{array}{l}\text { wholesale price } \\
\text { x2 } \sim_{3}\end{array}$ \\
\hline Manila & brass & 2000 picos & $\begin{array}{l}\text { wholesale price } \\
\text { x } 2\end{array}$ \\
\hline China & camphor & 200 picos & $\begin{array}{l}\text { wholesale price } \\
\text { x } 2_{2} \sim_{3}\end{array}$ \\
\hline China & ceramic & large quantity & $\begin{array}{l}\text { wholesale price } \\
\text { x } 1.2\end{array}$ \\
\hline China & $\begin{array}{l}\text { gold colored } \\
\text { furniture }\end{array}$ & & $\begin{array}{l}3000 \sim \\
4000 \text { cruzados }\end{array}$ \\
\hline China & $\begin{array}{l}\text { silk thread for } \\
\text { embroidery }\end{array}$ & & $\begin{array}{l}187 \sim_{208 \text { taeis/ }} \\
\text { picos }\end{array}$ \\
\hline China & $\begin{array}{l}\text { embroidered } \\
\text { beddings }\end{array}$ & & \\
\hline \multicolumn{4}{|l|}{$\begin{array}{l}\text { Goa } \Rightarrow \text { China } \\
\text { route }\end{array}$} \\
\hline India & silver & & \\
\hline
\end{tabular}




$\begin{array}{llll}\text { Price in Canton } & \text { Price in } & \text { Price in } & \text { Profit ratio } \\ \text { Macao } & \text { Japan } & & \text { Note }\end{array}$

$2.5 \sim_{3}$ taeis $/$

width of 12covado

piece

$5.4 \sim 6.6$ taeis

silver/1 tael gold

${ }_{7} \sim 8$ taeis/pico

8taeis/cattie

40 taeis/pico

40 taeis/pico

$1.5 \sim_{2}$

taeis/1pico

$1 \sim_{1.2}$ taeis/pico

8maces/pico

5.6 $\sim_{7}$ taeis $/$

pico

10 taeis/pico

1.5 taeis/pico
$80 \sim 90 \%$

$100 \%$

$100 \%$

$$
70 \sim 80 \%
$$

$70 \sim 80 \%$

$100 \sim 200 \%$

$100 \sim 200 \%$

$100 \%$

consumed in Bengal

to be sent to

Portugal

coins or embroidery

pieces 
TABLE 2.5 Price list of the commodity in the Portuguese intra-Asian trade of the 16th century (cont.)

\begin{tabular}{lll}
\hline Origin & Commodity & Price in Goa
\end{tabular}

\begin{tabular}{|c|c|c|c|}
\hline India & ivory & $2000 \sim 3000$ taeis & \\
\hline Spain & velvet & & $\begin{array}{l}6 \sim 7 \text { cruzados/ } \\
\text { covado }\end{array}$ \\
\hline Spain & scarlet & & $\begin{array}{l}5 \sim 8 \text { cruzados/ } \\
\text { covado }\end{array}$ \\
\hline Spain & wine(average) & $15^{0} \sim_{200}$ pipas & $\begin{array}{l}40 \sim_{50} \\
\text { cruzados/pipa }\end{array}$ \\
\hline Spain & wine(fine) & included above & $95 \mathrm{cruzados} /$ pipa \\
\hline Spain & olive oil & 6 pipas & $8 \sim_{10 \text { reals/jar }}$ \\
\hline $\begin{array}{l}\text { Spain } \\
\text { Prices in } \\
\text { Canton market }\end{array}$ & vinegar with caper & some barrels & \\
\hline China & gold (fine) & & \\
\hline China & musk & & \\
\hline China & raw silk & & \\
\hline China & $\begin{array}{l}\text { twisted thread } \\
\text { made in Nanjin }\end{array}$ & & \\
\hline China & damask (fine) & & \\
\hline China & damask(average) & & \\
\hline China & taffeta(fine) & & \\
\hline China & $\begin{array}{l}\text { silk } \\
\text { textile(average) }\end{array}$ & & \\
\hline China & cotton thread & & \\
\hline China & silk shawl & & \\
\hline China & $\begin{array}{l}\text { shawl braded of } \\
\text { silk thread }\end{array}$ & & \\
\hline China & cinnabar & & \\
\hline China & copper & & \\
\hline China & brass & & \\
\hline
\end{tabular}




$\begin{array}{lllll}\text { Price in Canton } & \text { Price in } & \text { Price in } & \text { Profit ratio } & \text { Note } \\ \text { Macao } & \text { Japan } & & \end{array}$

5otaeis/pico

\begin{tabular}{|c|c|c|}
\hline $\begin{array}{l}7 \sim 8 \text { taeis } / \\
\text { palmo }\end{array}$ & $240 \%$ & $\begin{array}{l}\text { 1covado }=66 \mathrm{~cm}, \\
\text { palmo }=22 \mathrm{~cm}\end{array}$ \\
\hline
\end{tabular}

\begin{tabular}{|c|c|c|}
\hline $80 \sim 90$ & $8 \circ \% \sim_{100} \%$ & upipa $($ barrel $) \doteqdot 8$ ool \\
\hline $\begin{array}{l}\text { cruzados } \\
(\max )\end{array}$ & & \\
\hline
\end{tabular}

$20 \%$ not to sell in Macao 12reals/jar in Manila

silver7taeis/taeis

8taeis/cattie

8otaeis/pico

8taeis in the original

13otaeis/pico

7 taeis/piece

width of 14 varas

$12 \sim_{15}$ taeis/

width of 16varas

piece

$2.5 \sim_{3}$ taeis/

width of 12 covados

piece

1.3maces/piece

width of 1ovaras

8taeis/pico

$3.5 \sim 4$ taeis/

piece

$4 \sim 5$ maces/

piece

4otaeis/pico

$7 \sim 8$ taeis/pico

$7 \sim 8$ taeis/pico 
TABLE 2.5 Price list of the commodity in the Portuguese intra-Asian trade of the 16th century (cont.)

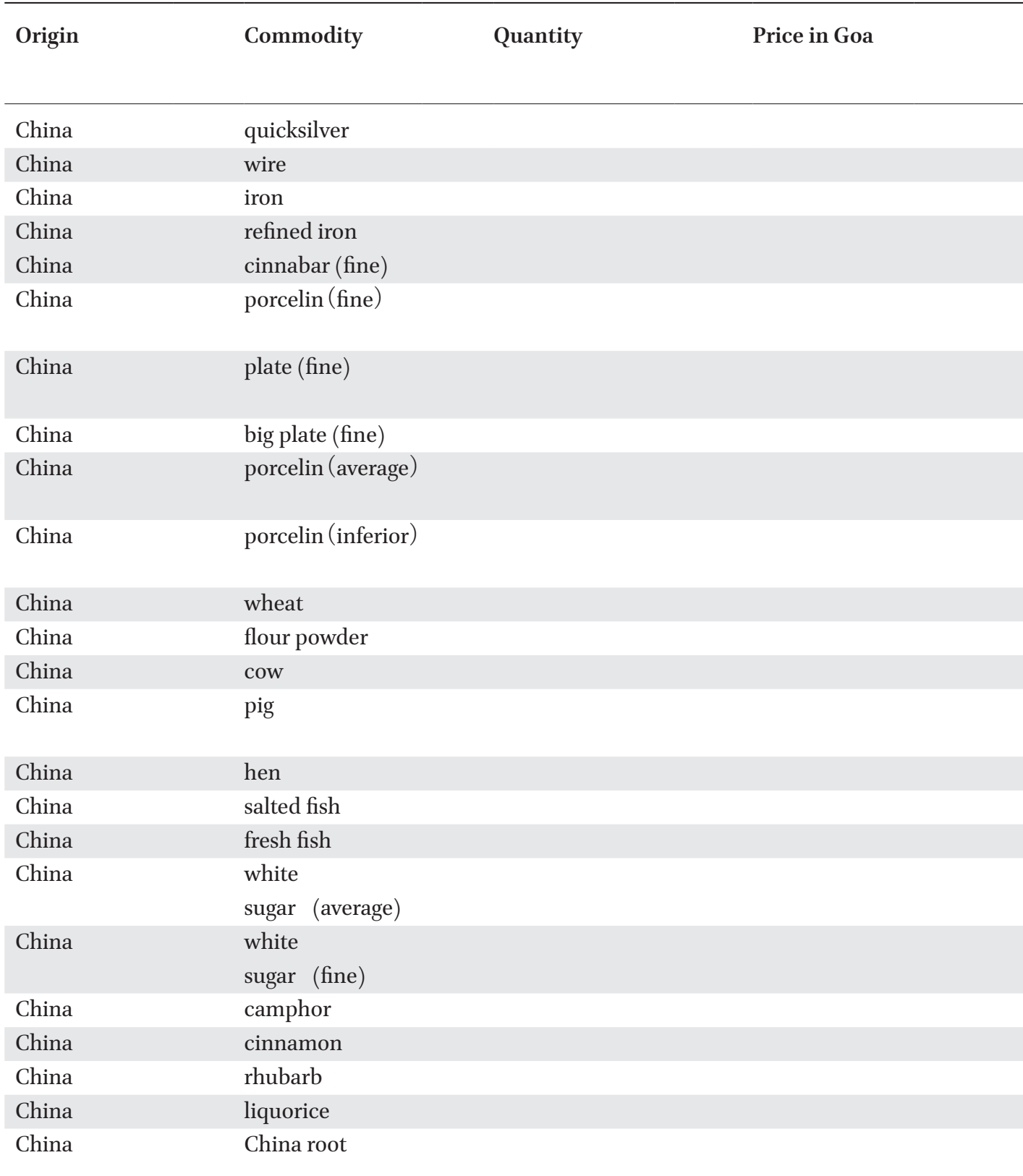




$\begin{array}{lllll}\text { Price in Canton } & \text { Price in } & \text { Price in } & \text { Profit ratio } & \text { Note } \\ & \text { Macao } & \text { Japan } & & \end{array}$

4otaeis/pico

8maces/pico

2taeis/pico

2.5 taeis/1pico

7omaces/cattie

1.2taeis/10

pieces

1.5 taeis/10

pieces

3maces/piece

1.5 maces $/ 10$

pieces

less than

1real/1o pieces

4 maces/pico

o.8taeis/pico $\quad 1.2$ taeis/pico

4taeis/each

1.5taeis/each $\quad 2 \sim_{3}$ taeis/

each

2taeis/1pico

2taeis/1pico

1conderin/1cattie

$1.5 \sim$ 2taeis/pico

2.5taeis/pico

1otaeis/pico

3 taeis/pico

${ }_{2} \sim_{3}$ taeis/pico

2.5taeis/pico

$0.8 \sim_{1 \text { taeis/pico }}$ 